\title{
Frequency of tongue lesions among outpatients attending a tertiary dermatology clinic in Turkey
}

\section{Türkiye'de üçüncü basamak bir dermatoloji kliniğine başvuran hastalarda dil lezyonlarının sıklı̆̆ı}

\author{
Ahu Yorulmaz ${ }^{1}$, Basak Yalcin ${ }^{1}$ \\ ${ }^{1}$ Dept. of Dermatology, Ankara Numune Research and Education Hospital, Ankara, Turkey
}

\begin{abstract}
Background The moist, pink, muscular tissue, tongue, serves as an organ of mastication, swallowing, tasting and vocalization. This highly specialized organ encompasses several cell types, which give rise to different kinds of diseases. There is a limited data on the prevalence rates of tongue diseases and factors associated with tongue lesions.

Objective The purpose of this study was to explore the prevalence rates of tongue diseases among outpatients of a large referral center and to determine factors associated with tongue diseases.

Methods This was a study of 1808 patients [769 men and 1039 women; mean age, $42.07 \pm 18.01$ years (range: 18-102 years)], who were prospectively enrolled between March 2016 and March 2017. Detailed demographic and clinical data, including tongue lesions were recorded. Mann-Whitney $\mathrm{U}$ and $\chi 2$ tests were used for statistical analysis, with a significance threshold of $\mathrm{p}<0.05$.

Results Tongue lesions were observed in 441 of 1808 patients (24.4\%). The most frequently observed disease of tongue were coated tongue (30.6\%), fissured tongue $(21.9 \%)$ and candidiasis $(16.3 \%)$. The general prevalence of these lesions were $7.5 \%, 5.1 \%$ and $4 \%$, respectively. Detailed statistical analysis revealed that age $(\mathrm{p}<0.001)$, gender $(\mathrm{p}<0.001)$, smoking habits $(\mathrm{p}<0.001)$, coffee consumption $(\mathrm{p}=0.012)$ and dental treatment history $(\mathrm{p}<0.001)$ were associated with higher rates of tongue diseases within the study group.

Conclusions We have demonstrated that tongue lesions were common in our study population. Further studies are needed to support these results.
\end{abstract}

Key words: tongue, prevalence, dermatology

\section{O̊zet}

Amaç Pembe, nemli ve kaslı bir doku olan dil, çiğneme, yutma, tat alma ve konuşma organıdır. Bu oldukça gelişmiş olan organ, birçok farklı hastalığa neden olan çok sayıda hücre tipini bünyesinde barındırmaktadır. Halihazırda literatürde dil hastalıkları prevalansı ve dil lezyonları ile ilişkili faktörler hakkında yeterli veri yoktur. Bu çalışmanın amacı büyük bir referans merkezine ayaktan başvuran hastalar arasında dil hastalıklarının sıklığını ve bu hastalıkları etkileyen faktörleri tespit etmektir.

Corresponding author: Ahu Yorulmaz, Dept. of Dermotology, Ankara Numune Research and Education Hospital, Ankara, Turkey Phone: +90 3125084000 - 56 31, Fax: +90 31231143 40, E-mail: ahuyor@gmail.com

Received: 4 May 2018 Accepted: 26 June 2018

Conflicts of Interest: None 
Yöntem Bu, Mart 2016 ile Mart 2017 yılları arasında 1808 hastanın [769 erkek ve 1039 kadın; ortalama yaş, $42.07 \pm 18.01$ yll (dağılım: 18-102 yıl)] prospektif olarak değerlendiridiği bir çalışmadır. Dil lezyonlarını da içeren ayrıntılı demografik ve klinik veriler kayıt altına alınmıștır. Mann-Whitney U ve $\chi 2$ testleri istatiksel analizlerde kullanılmıştır, $\mathrm{p}<0.05$ olan değerler istatiksel olarak anlamlı kabul edilmiştir.

Bulgular Dil lezyonları 441 (\%24.4) hastada görülmüştür. En sık tespit edilen dil lezyonu paslı dil (\%30.6), fissüre dil (\%21.9) ve kandidiyazis (\%16.3) idi. Bu lezyonların genel prevalansı sirasiyla \%7.5, \%5.1 ve \%4 idi. Ayrıntılı istatiksel analizler, yaş $(\mathrm{p}<0.001)$, cinsiyet $(\mathrm{p}<0.001)$, sigara kullanımı $(\mathrm{p}<0.001)$, kahve tüketimi $(\mathrm{p}=0.012)$, diş tedavisi hikayesinin $(\mathrm{p}<0.001)$ çalışma grubu içerisinde daha yüksek oranda dil hastalığı ile ilişkili olduğunu göstermiştir.

Sonuç Bu çalışma ile dil lezyonlarının çalışma grubumuzda sık olduğunu gösterdik. Bu sonuçları destekleyen ileri çalışmalara ihtiyaç vardır.

\section{Anahtar Kelimeler: dil, prevalans, dermatoloji}

\section{Introduction}

It has been claimed that the tongue is a mirror that reflects the general health status of an individual. ${ }^{1} \mathrm{Al}-$ though this legend still remains to be verified, it is obvious that the tongue is one of the most crucial organs in the body since it is engaged in swallowing, tasting, speech and respiration. ${ }^{1,2}$ Tongue is a muscular organ with highly specialized constituent tissues. Each of the biological composing components can give rise to a heterogeneous collection of lesions. ${ }^{1} \mathrm{Up}$ to date, there have been limited number of studies on the epidemiology of tongue lesions. ${ }^{3-8}$ The aim of the present study was to assess the prevalence of tongue lesions among dermatology outpatients in Turkish population. Moreover, we have also aimed to investigate the relationships between tongue lesions and oral health-related habits.

\section{Materials And Methods}

A total of 1808 patients [769 men and 1039 women; mean age, $42.07 \pm 18.01$ years (range: $18-102$ years)] were prospectively enrolled in the present study between March 2016 and March 2017. The study was conducted according to the principles of the Declaration of Helsinki and was approved by the local medical ethical committee. All the patients were given a description of the study and provided written informed consent. The only study inclusion criterion was being 18 years of age or older. A history including present dermatological disease, accompanying diseases, current medications, smoking habits, alcohol, tea and coffee consumption, dental treatment history (dental filling, crown and denture) and any antibiotic or mouthwash usage for the last two months was obtained from each subject. If the hospital application was related to a tongue lesion, it was noted. Patients were classified into three groups according to age: less than 35 years old (Group A), 35-65 years old (Group B) and over 65 years old (Group C). 'Packyears' (PY) measurement, which is the the product of duration and smoking rate, was calculated for all smoking patients. Accordingly, smoking habits were rated on a 4-point scale as: $1=$ 'PY $<5$ ', $2=$ ' $5 \leq \mathrm{P}<20$ ', $3=$ ' 20 $\leq \mathrm{PY}<40$ ' and $4=$ 'PY $\geq 40$ '. Alcohol consumption was rated as 'daily', 'several times a week', 'rarer than once a month' and 'never'. Those who had quitted smoking and alcohol consumption were also recorded. Tea consumption was recorded on a 3-point scale, which include $1=$ less than 2 cups per day, $2=2-5$ cups per day and $3=$ more than 5 cups per day. Coffee consumption was also recorded on 3-point scale, that include $1=$ less than 2 cups per day, $2=2-5$ cups per day and $3=$ more than 5 cups per day.

Dermatological diseases were categorized as follows: acne and related diseases, cutaneous infections, contact dermatitis, urticaria and angioedema, pruritus and pruritic dermatoses, psoriasis and related diseases, blistering dermatoses, lichen planus and lichenoid disorders, other inflammatory dermatoses, connective tissue diseases, drug reactions, pigmentary disorders, hair disorders, nail disorders, neoplastic changes, dermatoses resulting from physical factors, oral mucosal diseases and diseases of tongue. A thorough dermatological examination including oral mucosal examination was carried 
out for each patient. Diseases of tongue were recorded as follows: fissured tongue, geographic tongue, coated tongue, hairy tongue, macroglossia, sublingual varices, glossitis, lichen planus, recurrent aphthous ulcer, candidiasis, angina bullosa haemorrhagica, mucous patches of syphilis, pemphigus vulgaris, oral frictional hyperkeratosis, wart, physiologic (ethnic) pigmentation, transient lingual papillitis, oral irritated fibroma, caustic and heat injuries.

The statistical analysis was performed by using SPSS software (version 20; SPSS Inc., Chicago IL, USA). Descriptives and frequencies were calculated for variables related to demographic and clinical characteristics of patients. Age was described as mean \pm standard deviation and range. Associations between qualitative variables were tested by Chi-square ( $\chi 2)$ or Fisher's exact test. The Mann-Whitney U test was also used to analyze the associations between demographic and clinical variables of the patients. A p-value of $<0.05$ was considered to be statistically significant.

\section{Results}

$39.3 \%$ of the patients $(\mathrm{n}=710)$ were in the age group of A ( $<35$ years old $), 47.9 \%(n=866)$ were in the group B (35-65 years old), $12.8 \%$ of the patients $(\mathrm{n}=232)$ were in the group C ( $>65$ years old). Accompanying diseases were recorded in 698 of 1808 patients (38.7\%), and a medication history was reported by 632 of 1808 patients (35\%). Table 1 demonstrates the frequencies of accompanying diseases. 293 of 1808 patients (16.2\%) were current smokers and 79 of the patients (4.4\%) had a smoking history. According to smoking habits 4-point scale, $4.9 \%$ of the patients $(\mathrm{n}=88)$ were in the group 1 $(\mathrm{PY}<5), 6.9 \%(\mathrm{n}=125)$ were in the group $2(5 \leq \mathrm{P}<20)$, $3.7 \%(n=66)$ were in the group $3(20 \leq P Y<40), 0.8 \%$ $(n=14)$ of the patients were in the group 4 (PY $\geq 40$ ). $85.8 \%(\mathrm{n}=1552)$ of the patients never drank alcohol, $14.2 \%(n=256)$ of the patients were current drinkers or had a history of alcohol consumption. 5.7\% $(n=103)$ of the individuals were daily drinkers, $0.6 \%(n=10)$ were drinkers of 'several times a week' and 7.9\% ( $\mathrm{n}=143)$ were drinkers of 'rarer than once a month'.
$0.2 \%$ of the patients $(n=4)$ reported that they did not drink tea. $87.4 \%$ of the patients $(\mathrm{n}=1580)$ used to drink less than 2 cups per day, 8.9\% $(n=161)$ drank 2-5 cups per day and $3.5 \%(n=63)$ of the patients drank more than 5 cups per day. $85.7 \%$ of the patients $(n=1550)$ reported that they drank less than 2 cups of coffee per day, $7.3 \%(\mathrm{n}=132)$ drank $2-5$ cups of coffe per day, $2.4 \%$ ( $\mathrm{n}=44)$ drank more than 5 cups of coffee per day and $4.5 \%$ of the patients $(n=82)$ were non-drinkers. $44 \%$ of the patients $(\mathrm{n}=795)$ did not have a dental treatment history. 28.2\% ( $\mathrm{n}=509$ ) had dental filling, 15.3\% ( $\mathrm{n}=$ 277) had dental crown, $12.6 \%(n=227)$ had denture. $11.1 \%$ of the patients $(n=201)$ reported that they had had antibiotic treatment in the previous two months and $2.7 \%(\mathrm{n}=48)$ had used mouthwash in the previous two months.

Table 1. Frequencies of accompanying diseases in the study group

\begin{tabular}{lc} 
Accompanying diseases & $\mathbf{n}(\mathbf{\%})$ \\
Cardiovascular diseases & $219(31.4)$ \\
Endocrine diseases & $153(21.9)$ \\
Neuropsychiatric diseases & $88(12.6)$ \\
Gastrointestinal diseases & $45(6.4)$ \\
Solid and hematologic malignancies & $43(6.2)$ \\
Pulmonary diseases & $39(5.6)$ \\
Rheumatological diseases & $28(4.0)$ \\
Other & $26(3.7)$ \\
Hematologic and nutritional deficiencies & $25(3.6)$ \\
Infectious diseases & $18(2.6)$ \\
Renal diseases & $14(2.0)$ \\
\hline
\end{tabular}

Table 2 shows the frequencies of dermatological diseases in the study group. Tongue lesions were observed in 441 of 1808 patients (24.4\%). However, only in 39 of 1808 patients (2.2\%) hospital application was related to a tongue disease. Frequencies of tongue diseases in the study group were demonstrated in Table 3. The most frequently observed tongue diseases were coated tongue $(30.6 \%)$, fissured tongue $(21.9 \%)$ and candidia- 
sis $(16.3 \%)$. The general frequency of these lesions were $7.5 \%, 5.1 \%$ and $4 \%$, respectively. In $1.7 \%$ of the patients $(n=30)$ combination of both fissured and geographic tongue was observed.

Table 2. Frequencies of dermatological diseases in the study group

\begin{tabular}{lc}
\hline Dermatological diseases & $\mathbf{n}(\%)$ \\
Cutaneous infections & $420(23.2)$ \\
Contact dermatitis & $318(17.6)$ \\
Acne and related diseases & $273(15.1)$ \\
Pruritus / pruritic dermatosis & $200(11.1)$ \\
Neoplastic changes & $113(6.3)$ \\
Urticaria and angioedema & $105(5.8)$ \\
Psoriasis and related diseases & $79(4.4)$ \\
Hair disorders & $73(4.0)$ \\
Dermatosis related physical factors & $54(3.0)$ \\
Other inflammatory dermatosis & $38(2.1)$ \\
Nail diseases & $31(1.7)$ \\
Diseases of tongue & $29(1.6)$ \\
Blistering dermatosis & $21(1.2)$ \\
Connective tissue diseases & $18(1.0)$ \\
Oral mucosal diseases & $17(0.9)$ \\
Lichen planus and lichenoid disorders & $16(0.8)$ \\
Pigmentary disorders & $3(0.2)$ \\
\hline
\end{tabular}

Coated tongue and sublingual varices were observed significantly more frequently in men than in women $(5.1 \%$ vs. $2.4 \%, \mathrm{p}<0.001 ; 1.2 \%$ vs. $0.6 \%, \mathrm{p}=0.007$, respectively). Patients in the age group B were significantly more likely to have coated tongue and candidiasis $(5.2 \%, \mathrm{p}<$ $0.001 ; 2.4 \%, p=0.03$, respectively). When compared to study group individuals in the age group $\mathrm{C}$ were significantly more likely to have glossitis and sublingual varices $(1.1 \%, \mathrm{p}<0.001 ; 0.9 \%, \mathrm{p}<0.001$, respectively). There were not any significant association between accompanying diseases and prevalence rates of tongue lesions, neither current medications nor prevalence rates of tongue lesions. Patients who smoked as described grade 3, according to 4-point scale were significantly more likely to have hairy tongue $(0.2 \%, \mathrm{p}<0.001)$. No significant association was detected between alcohol and tea consumption and prevalence rates of tongue lesions.

Table 3. Frequencies of tongue diseases in the study group

\begin{tabular}{|c|c|c|}
\hline Tongue diseases & n $\quad(\% *)$ & $\%$ ** \\
\hline Coated tongue & $135(30.6)$ & 7.5 \\
\hline Fissured tongue & $93(21.9)$ & 5.1 \\
\hline Candidiasis & $72(16.3)$ & 4.0 \\
\hline Geographic tongue & $32(7.3)$ & 1.8 \\
\hline Sublingual varices & $31(7.0)$ & 1.7 \\
\hline Glossitis & $29(6.6)$ & 1.6 \\
\hline Recurrent aphthous ulcer & $8(1.8)$ & 0.4 \\
\hline Transient lingual papillitis & $8(1.8)$ & 0.4 \\
\hline Caustic and heat injuries & $7(1.6)$ & 0.4 \\
\hline Oral frictional hyperkeratosis & $5(1.1)$ & 0.3 \\
\hline Oral irritated fibroma & $4(0.9)$ & 0.2 \\
\hline Hairy tongue & $4(0.9)$ & 0.2 \\
\hline Physiologic (ethnic) pigmentation & $3(0.7)$ & 0.2 \\
\hline Lichen planus & $3(0.7)$ & 0.2 \\
\hline Wart & $2(0.5)$ & 0.1 \\
\hline Pemphigus vulgaris & $2(0.5)$ & 0.1 \\
\hline Angina bullosa haemorrhagica & $1(0.2)$ & 0.1 \\
\hline Mucous patches of syphilis & $1(0.2)$ & 0.1 \\
\hline Macroglossia & $1(0.2)$ & 0.1 \\
\hline
\end{tabular}

Individuals who used to drink coffee less than 2 cups per day were significantly more likely to have coated tongue and candidiasis when compared to study group (4.5\%, p $<0.001 ; 3 \%, p=0.032$, respectively). In addition, patients who used to drink 2-5 cups of coffee per day were significantly more likely to have hairy tongue $(0.2 \%, p=0.001)$. Patients who had crown were signifi- 
cantly more likely to have oral frictional hyperkeratosis $(0.2 \%, p=0.028)$. There were not any significant associations between antibiotic treatment nor prevalence rates of tongue lesions, neither mouthwash usage and prevalence rates of tongue lesions. $97.4 \%$ of the patients, who had applied with a tongue lesion, literally had tongue lesion. On the other hand, 2.6\% of the patients who applied with a tongue lesion did not have any tongue disease. $24.5 \%$ of the patients, who did not apply with a tongue lesion, turned out to have a tongue disease. Moreover, $91.9 \%$ of the patients, who had tongue disease, did not apply for the tongue lesion. The only significant association between hospital application for tongue disease and tongue lesion was observed in patients with recurrent aphthous ulcer. Patients with recurrent aphthous ulcer were significantly more likely to apply for the tongue lesion $(0.3 \%, \mathrm{p}<0.001)$. No significant association was observed between dermatological diseases and tongue diseases.

\section{Discussion}

Current literature on the prevalence rates of tongue diseases in general populations is still limited. This study is one of the few studies exploring the prevalence rates of tongue diseases and factors associated with tongue lesions. We have found that the prevalence of tongue lesions was $24.4 \%$ and the most frequently observed lesion was coated tongue $(30.6 \%)$. The prevalence rate of coated tongue in general population was $7.5 \%$. Coated tongue has been described as the condition, in which the dorsum of tongue is covered with debris. In coated tongue the length of the filiform papillae is less than $3 \mathrm{~mm}$, while in hairy tongue it is more than $3 \mathrm{~mm} .^{3}$ The prevalence rate of coated tongue in different studies varies. ${ }^{3,7,9,10}$ However, in general it has been suggested that coated tongue is closely associated with smoking, alcohol and tea consumption. ${ }^{3,7,9}$ In this study, we have shown that individuals who used to drink coffee less than 2 cups per day were significantly more likely to have coated tongue. We have also demonstrated that patients who used to drink 2-5 cups of coffee per day and patients who smoked grade 3 according to 4-point scale were significantly more likely to have hairy tongue. But, according to our study there were not any significant associations between antibiotic treatment and prevalence rates of tongue lesions, neither mouthwash usage nor prevalence rates of tongue lesions. However, it has been suggested that the etiological factors of hairy tongue include not only smoking and tea consumption, but also history of antibiotic treatment and antiseptic mouthwash usage. $3,11,12$

One of the relevant findings of our study was to describe associations of age and gender with the prevalence rates of tongue lesions. We have demonstrated that coated tongue and sublingual varices were observed significantly more frequently in men than in women. Patients in the age group B were significantly more likely to have coated tongue and candidiasis. Individuals in the age group $\mathrm{C}$ were significantly more likely to have glossitis and sublingual varices. Sublingual varices are benign vascular dilatations, usually seen along the ventral surface of the tongue and tend to become more prominent with aging. Despite the limited current literature, it is known that men are affected more frequently than women. ${ }^{13}$

In the present study, the second most commonly observed tongue lesion was fissured tongue. Fissured tongue is a benign condition, manifested with grooves that can vary in size and depth. Although the exact etiology of fissured tongue has not been described yet, a polygenic mode of inheritance is theorized. Fissured tongue is commonly seen in association with geographic tongue. ${ }^{14}$ We have also shown that in $1.7 \%$ of our patients fissured and geographic tongue were observed concominantly. Fissured ${ }^{15}$ and geographic tongue ${ }^{16}$ are both seen more commonly in patients with psoriasis. However, we could not prove this association.

One of relevant study about tongue lesions was done by Avcu et al. ${ }^{3}$ Avcu et al. investigated the prevalance of tongue lesions in 5150 Turkish dental outpatients. They found that of the 5150 subjects, 2690 subjects were detected as having tongue lesions with a prevalance of $44.2 \%$ and $62 \%$ for women and men, respectively. They also found that there was a strong correlation between tongue lesions and increasing age. In addition, signif- 
icant associations were demonstrated between smoking, tea consumption, poor oral hygiene and prevalance rates of tongue lesions. ${ }^{3}$ Although, this study is one of the comparable one with ours, the fact that Avcu et al. evaluated the patients from the view of dentists might probably lead the different results.

We suggest that our study is one of the few studies exploring the prevalence rates of tongue lesions among general population also investigating the relationships between tongue lesions and oral health-related habits. However, we have several limitations, one of which is relatively small number of participants. Moreover, we did not detect well-known relationships, including dermatological diseases and tongue lesions associations. On the other hand, as far as we know there is not any study in the literature investigating the relationship of tongue lesions with hospital application. We have shown that $2.6 \%$ of the patients who applied with a tongue lesion did not have any tongue disease. $24.5 \%$ of the patients, who did not apply with a tongue lesion, turned out to have a tongue disease. Moreover, 91.9\% of the patients, who had tongue disease, did not apply for the tongue lesion. These results were outstanding. Another particular finding was that the only significant association between hospital application for tongue disease and tongue lesion was observed in patients with recurrent aphthous ulcer. Although several remarkable findings were demonstrated in the present study, we think that further studies are needed to clarify other factors that affect tongue lesions, including food and dietary habits.

\section{References}

1. Shamloo N, Lotfi A, Motazadian HR, Mortazavi $\mathrm{H}$, Baharvand M. Squamous cell carcinoma as the most common lesion of the tongue in Iranians: a 22-year retrospective study. Asian Pac J Cancer Prev 2016;17:1415-9.

2. Mu L, Sanders I. Human tongue neuroanatomy: Nerve supply and motor endplates. Clin Anat 2010;23:777-91.

3. Avcu N, Kanli A. The prevalence of tongue lesions in 5150 Turkish dental outpatients. Oral Dis 2003;9:188-95.

4. Bánóczy J, Rigó O, Albrecht M. Prevalence study of tongue lesions in a Hungarian population. Commu- nity Dent Oral Epidemiol 1993;21:224-6.

5. Darwazeh AM, Almelaih AA. Tongue lesions in a Jordanian population. Prevalence, symptoms, subject's knowledge and treatment provided. Med Oral Patol Oral Cir Bucal 2011;16:e745-9.

6. Gambino A, Carbone M, Arduino PG, et al. Clinical features and histological description of tongue lesions in a large Northern Italian population. Med Oral Patol Oral Cir Bucal 2015;20:e560-5.

7. Patil S, Kaswan S, Rahman F, Doni B. Prevalence of tongue lesions in the Indian population. J Clin Exp Dent 2013;5:e128-32.

8. Vörös-Balog T, Dombi C, Vincze N, Bánóczy J. Epidemiologic survey of tongue lesions and analysis of the etiologic factors involved. Fogorv Sz 1999;92:157-63.

9. Gönül M, Gül U, Kaya I, et al. Smoking, alcohol consumption and denture use in patients with oral mucosallesions. J Dermatol Case Rep 2011;5:64-8.

10. Yorulmaz A, Dogan S, Kilic A, Onan TD, Artüz F. Dermatoloji poliklinigine basvuran hastalarda oral mukoza hastaliklarinin arastirilmasi: 1670 hasta kapsayan bir çalisma. Turkiye Klinikleri J Med Sci 2016;36:73-85.

11. Gurvits GE, Tan A. Black hairy tongue syndrome. World J Gastroenterol 2014;20:10845-50.

12. Gökdemir G. Benign pigmented lesions of oral mucosa. Türkderm 2012;46:66-71.

13. Al-Shayyab MH, Baqain ZH. Sublingual varices in relation to smoking, cardiovascular diseases, denture wearing, and consuming vitamin rich foods. Saudi Med J 2015;36:310-5.

14. Sudarshan R, Sree Vijayabala G, Samata Y, Ravikiran A. Newer classification system for fissured tongue: an epidemiological approach. J Trop Med 2015;2015:262079.

15. Picciani BLS, Teixeira-Souza T, Pessôa TM, et al. Fissured tongue in patients with psoriasis. J Am Acad Dermatol 2018;78:413-4.

16. Tarakji B, Umair A, Babaker Z, Sn A, Gazal G, Sarraj F. Relation between psoriasis and geographic tongue. J Clin Diagn Res 2014;8:6-7. 